DOI: 10.20472/AHC.2019.005.014

\title{
NAGENDRA KUMAR
}

Indian Institute of Technology Roorkee, India

\section{ALL'S WELL THAT ENDS WELL; THE END WAS NEVER WELL: COLLECTIVE MEMORY IN KHUSHWANT SINGH'S TRAIN TO PAKISTAN}

\begin{abstract}
:
The birth of two independent nations India and Pakistan from Hindustan in 1947 was not an easy process. The partition which was conceived for peace, harmony and order brought only violence and hostility on both parts of the country at that point in time. The repercussion of the partition can be seen in the present day also as durable peace since then has never been achieved between the two countries. The poignant partition inspired literature, which has collected the partition experiences of common folk. The partition literature which emerged as a separate genre of literature is a medium of cultural memory which helps in shaping the sensibility of contemporary readers. The present article seeks to examine the role of partition in degenerating the relationship between India and Pakistan and the collective memory shared by the contemporary people by a reading of Khushwant Singh's Train to Pakistan, a masterpiece of partition literature.
\end{abstract}

\section{Keywords:}

Partition, collective memory, India, Literature, Pakistan, Khushwant Singh.

JEL Classification: E01 